\title{
Pendekatan Humanis Dalam Tes Pengajaran Bahasa Arab
}

\author{
Muhammad Yusuf \\ Universitas Islam Negeri Sunan Kalijaga Yogyakarta \\ Corresponding author: elyusuf03@gmail.com
}

\begin{abstract}
The purpose of this article is to discuss the humanism approach in Arabic teaching tests. This paper relies on bibliographic sources in the form of books and articles (literature study) that are in a scientific journal related to the subject matter. Reading the data of academics' thinking by using a constructive critical approach and meaningful content with content analysis. Based on studies that have been conducted, teaching tests in the humanist approach must be proportional in measuring each domain that exists in students (cognitive, affective, and psychomotor). The form of tests to measure the domain of cognition can be done by presenting objective tests and description tests. As for the affection domain measurement, it can be done by compiling a Likert scale and semantic different. Meanwhile, to measure the psychomotor domain test can be done in the form of task analysis.
\end{abstract}

Tujuan dari penulisan artikel ini adalah untuk mendiskusikan pendekatan humanisme dalam tes pengajaran bahasa Arab. Tulisan ini mengandalkan sumber bibliografis berupa buku dan artikel (studi pustaka) yang berada di jurnal ilmiah yang berkaitan dengan pokok permasalahan. Pembacaan data pemikiran para akademisi dengan menggunakan pendekatan konstruktif kritis dan pemaknaan substansinya dengan analisis isi. Berdasarkan kajian yang telah dilakukan, tes pengajaran dalam pendekatan humanis harus proporsional dalam mengukur setiap domain yang ada pada siswa (kognitif, afektif, dan psikomotorik). Adapun bentuk

ISSN 2622-6146 (e) 2622-6138 (p)

(C) 2019 Alsina : Journal of Arabic Studies

http://journal.walisongo.ac.id/index.php/alsina 
tes untuk mengukur domain kognisi bisa dilakukan dengan menyajikan tes objektif dan tes uraian. Sedangkan untuk pengukuran domain afeksi bisa dilakukan dengan cara penyusunan skala likert dan semantic different. Sementara untuk mengukur domain psikomotor dapat dilakukan tes berupa task analysis.

Keywords: Bahasa Arab; pendekatan humanis; tes pengajaran.

\section{Pendahuluan}

Faktor penentu keberhasilan dalam pembelajaran selain materi, metode, motivasi, dan tujuan dalam kegiatan pengajaran, yang tidak kalah pentingnya adalah evaluasi. Evaluasi adalah proses sistematis untuk mengetahui (menguji) apakah suatu program, proses kegiatan telah sesuai dengan tujuan dan kriteria yang telah ditentukan. Lebih lanjut, Fathul Mujib (2010) berpendapat bahwa evaluasi memiliki peranan yang sangat signifikan dalam upaya meraih keberhasilan pembelajaran. Hasil dari evaluasi merupakan informasi yang sangat diperlukan guna melakukan perbaikan dan penyempurnaan dalam penyelenggaraan pembelajaran. Oleh karenanya, evaluasi merupakan bagian integral yang tidak dapat dipisahkan dari kegiatan pembelajaran. ${ }^{1}$ Termasuk di dalamnya pembelajaran bahasa Arab.

Salah satu alat evaluasi dalam proses pembelajaran adalah tes pengajaran. Tes menurut Anas Sudijono (2011) adalah cara atau prosedur yang perlu ditempuh dalam rangka pengukuran dan penilaian di bidang pendidikan, yang berbentuk pemberian tugas atau serangkaian tugas, atau instruksi guru, sehingga atas dasar data yang diperoleh dari hasil pengukuran tersebut dapat dihasilkan nilai yang melambangkan tingkah

${ }^{1}$ Fathul Mujib, Rekonstruksi Pendidikan Bahasa Arab "Dari Pendekatan Konvensional Ke Integratif Humanis" (Yogyakarta: Pedagogia, 2010), 159. 
laku atau prestasi siswa. ${ }^{2}$ Bila diimpresikan dalam pembelajaran bahasa Arab, tes pengajaran dapat dinarasikan sebagai sebuah prosedur yang ditempuh seorang pendidik dalam jangka waktu tertentu untuk mengukur sejauh mana kompetensi bahasa Arab (yang meliputi kompetensi pengetahuan, kompetensi keterampilan atau kemahiran, dan kompetensi sikap kebahasaan) yang didapat oleh peserta didik dalam proses pembelajaran.

Dalam dataran realitas, sebagaimana pendapat Fathul Mujib (2010), dalam tes pengajaran bahasa Arab masih dijumpai banyak problem, salah satunya berkaitan dengan aspek proporsionalitas tes. Sejauh ini, aspek yang diteskan dalam pengajaran bahasa Arab mendewakan aspek kognitif dan mendeskreditkan aspek yang lain seperti afeksi dan psikomotor. ${ }^{3} \mathrm{Hal}$ ini agaknya sebagai konsekuensi logis dari paradigma konvensional yang memandang pembelajaran bahasa berarti memahami bahasa.

Dalam kaitan tersebut, agaknya menjadi penting untuk merekonstruksi paradigma tes pengajaran yang sejauh ini diwarnai dengan pendekatan konvensional atau traditional. Salah satu trend pendekatan yang sedang berkembang dewasa ini adalah pendekatan humanis. ${ }^{4}$ Dalam konteks pembelajaran bahasa Arab, salah satu tokoh yang menyuarakan tentang pendekatan ini adalah Fathul Mujib. Hal itu terlihat dari salah satu bukunya yang membahas tentang rekonstruksi pengajaran bahasa Arab.

Tulisan ini bertujuan untuk mendiskusikan permasalahan penting dan menarik, yaitu pendekatan humanis dalam tes

2 Ibid, h. 67.

${ }^{3}$ Ibid, h.158-159.

${ }^{4}$ Humanisasi pendidikan adalah proses pendidikan yang lebih memperhatikan aspek potensi (fitrah) manusia sebagai makhluk sosial, makhluk religius, hamba Allah, dan khalifah Allah serta sebagai individu yang memiliki potensi intelektual dan spiritual yang tinggi. Ibid. 
pengajaran bahasa Arab. Tulisan ini mengandalkan sumber bibliografis berupa buku dan artikel yang berada dijurnal ilmiah yang berkaitan dengan pokok permasalahan. Pembacaan data pemikiran para akademisi dengan menggunakan pendekatan konstruktif kritis dan pemaknaan substansinya dengan analisis isi. ${ }^{5}$

\section{Landasan Teori}

\section{Pengertian Tes Bahasa Arab}

Secara etimologi kata tes $^{6}$ berasal dari bahasa Perancis Kuno testum dengan arti piring untuk menyisihkan logamlogam mulia. ${ }^{7}$ Dalam bahasa Inggris disebut dengan test yang dalam bahasa Indonesia ditulis dengan tes yang mempunyai arti ujian atau percobaan. ${ }^{8}$ Adapun secara terminologi, Anas Sudijono (2011) berpendapat, bahwa tes adalah cara atau prosedur yang perlu ditempuh dalam rangka pengukuran dan penilaian di bidang pendidikan, yang berbentuk pemberian tugas atau serangkaian tugas, atau intruksi guru, sehingga atas dasar data yang diperoleh dari hasil pengukuran tersebut dapat dihasilkan nilai yang melambangkan tingkah laku atau

${ }^{5}$ Content analysis adalah telaah sistematik untuk menganalisis isi pesan dan mengolah pesan atas catatan-catatan atau dokumen sebagai sumber data, sehingga diperoleh suatu hasil atau pemahaman terhadap berbagai isi pesan komunikasi yang disampaikan secara terbuka, obyektif dan sistematik. Lihat Dalam Sanapiah Faisal, Metodologi Penelitian Pendidikan (Surabaya: Usaha Nasional, 1982), 133.

${ }^{6}$ Tes dalam kamus bahasa Arab modern karangan Hans Wehr (1974) diarabkan dengan istilah ikhtibar. Selain kata tersebut, tes juga dapat diarabkan dengan imtihan, namun agaknya kata ikhtibar lebih populer daripada kata imtihan. Lihat dalam Abdul Hamid, Mengukur Kemampuan Bahasa Arab Untuk Studi Islam (Malang: UIN-Maliki Press, 2010), 8.

${ }^{7}$ Maksudnya dengan menggunakan alat berupa piring itu akan dapat diperoleh jenis-jenis logam mulia yang nilainya sangat tinggi. Lihat dalam Anas Sudijono, Pengantar Evaluasi Pendidikan (Jakarta: PT Raja Grafindo Persada, 2011), 66.

${ }^{8}$ Ibid. 
prestasi siswa. ${ }^{9}$ Sementara itu Muri Yusuf (2015) berpendapat, tes merupakan salah satu alat yang dapat digunakan pendidik untuk memahami tingkat keberhasilan peserta didik. ${ }^{10}$ Dalam narasi yang lain, Ngalim Purwanto (1988) berpendapat bahwa tes atau achievement test adalah tes yang dipergunakan untuk menilai hasil-hasil pelajaran yang telah diberikan guru kepada muridnya, atau oleh dosen kepada mahasiswa, dalam jangka waktu tertentu. ${ }^{11}$ Berdasarkan pengertian para ahli tersebut dapat diambil kesimpulan, bahwa tes merupakan prosedur yang ditempuh seorang pendidik dalam jangka waktu tertentu untuk mengukur sejauh mana kompetensi yang didapat oleh peserta didik dalam proses pembelajaran. Bila dikontekstualisasikan dengan pengajaran bahasa Arab maka dapat dideskripsikan bahwa tes merupakan prosedur yang ditempuh seorang pendidik dalam jangka waktu tertentu untuk mengukur sejauh mana kompetensi bahasa Arab (yang meliputi kompetensi pengetahuan, kompetensi keterampilan atau kemahiran, dan kompetensi sikap kebahasaan) yang didapat oleh peserta didik dalam proses pembelajaran.

\section{Pendekatan Tes Bahasa}

Dalam penyelenggaran pembelajaran bahasa, tes bahasa merupakan bagian dari keseluruhan dari penyelenggaraan pembelajaran bahasa, khususnya sebagai bagian dari komponen evaluasi hasil pembelajaran. Dalam kaitan tersebut, tes bahasa memiliki kaitan yang amat erat dengan komponenkomponen lain dalam penyelenggaraan pembelajaran bahasa, terutama komponen pembelajaran yang mendasarinya, yaitu

${ }^{9}$ Ibid, h. 67.

10 Muri Yusuf, Asesmen dan Evaluasi Pendidikan (Jakarta: Prenadamedia Group, 2015), 181.

${ }^{11}$ Ngalim Purwanto, Prinsip-prinsip dan Tekhnik Evaluasi Pengajaran (Bandung: Remadja Karya, 1988), 45. 
kegiatan pembelajaran. Hal serupa berlaku pula sebaliknya terhadap komponen kegiatan pembelajaran itu sendiri yang amat erat kaitannya dengan komponen tujuan pembelajaran yang mendasarinya. Kaitan itu tercermin dalam berbagai unsur penyelenggaraan tes, tidak saja dalam hal cakupan dan rincian isi tes yang diselenggarakan, melainkan juga dalam hal dasar dan hakikat penyelenggaraannya, termasuk pandangan dasar terhadap bahasa yang merupakan bidang garapan pokok suatu pembelajaran bahasa. Secara umum dapat dikatakan bahwa pandangan terhadap bahasa menentukan pendekatan pembelajaran bahasa, dan pendekatan pembelajaran bahasa menentukan pendekatan dalam penyelenggaraan tesnya.

\section{Pendekatan Tradisional}

Pendekatan tradisional dalam tes bahasa dikaitkan dengan bentuk pembelajaran bahasa tradisional yang penyelenggaraannya didasarkan atas kajian terhadap seluk beluk bahasa (struktur bahasa). Orientasi dari pembelajaran yang menggunakan pendekatan ini hanya terbatas untuk menguasai naskah tertulis (menerjemahkan) atau berkomunikasi secara terbatas. Secara operasional, penyelenggaraan tes bahasa diwarnai dengan berbagai bentuk subjektifitas dalam hal pemilihan kemampuan bahasa yang dijadikan sasaran, pemilihan dan penetapan bahan dan isi tes, serta cara penilaian pekerjaan peserta tes. ${ }^{12}$

2. Pendekatan Diskret ${ }^{13}$

\footnotetext{
12 Soenardi Djiwandono, Tes Bahasa: Pegangan Bagi Pengajar Bahasa (Jakarta: Anggota IKAPI, 2011), 18-19.

${ }^{13}$ Dasar pemikiran teori diskret, baik dalam pembelajaran maupun penilaian, berasal dari teori strukturalisme dalam linguistik dan teori behaviorisme dalam psikologi. Baik teori strukturalisme ataupun behaviorisme mengakui bahwa suatu bentuk keseluruhan dapat dipecah menjadi bagian-bagian tertentu. Tiap aspek bahasa atau kemampuan bahasa tersebut kemudian dapat diajarkan secara sendiri terlepas dari konteks keseluruhan dan situasi pemakaian kebahasaan yang konkret. Lihat dalam Burhan Nurgiantoro, Penilaian Pembelajaran Bahasa Berbasis Kompetensi (Yogyakarta: Anggota IKAPI, 2013), 285.
} 
Dalam terminologi Oller (1979), sebagaimana dikutip oleh Burhan Nurgiyantoro, tes diskret ${ }^{14}$ (discrete poin test) adalah tes yang hanya menekankan satu aspek kebahasaan pada satu waktu. Tiap satu butir soal hanya dimaksudkan untuk mengukur satu aspek kebahasaan, misalnya fonologi, morfologi, sintaksis, atau kosakata. Lebih lanjut, Oller (1979) juga menjelaskan bahwa tes yang bersifat diskret tidak hanya menyangkut aspek kebahasaan saja, melainkan juga dapat berbagai macam kemampuan berbahasa. Maka bisa diasumsikan, bila sebuah tes bahasa secara khusus dimaksudkan untuk mengukur salah satu kemampuan berbahasa saja, misalnya menyimak, membaca, berbicara, atau menulis, tanpa mengaitkannya dengan kemampuan yang lain, tes kemampuan berbahasa tersebut termasuk tes diskret. ${ }^{15}$

\section{Pendekatan Integratif}

Pendekatan integratif mempunyai landasan teori linguistik yang sama dengan pendekatan diskret. Dapat dikatakan bahwa tes integratif merupakan koreksi terhadap kelemahan yang terdapat dalam tes diskret. Bila dalam tes diskret pada satu waktu hanya mengeteskan satu aspek kebahasaan saja, dalam tes integratif berusaha mengukur kemampuan siswa mempergunakan berbagai aspek kebahasaan atau beberapa kemampuan berbahasa. Jadi, tes integratif adalah suatu tes kebahasaan yang berusaha mengukur beberapa aspek kebahasaan atau kemampuan berbahasa pada satu waktu. ${ }^{16}$ Dalam perspektif Nurgiyantoro (1988), sebagaimana dikutip oleh

${ }^{14}$ Istilah lain yang semakna dengan tes diskret menurut Morrow (1979), sebagaimana dikutip Ainin dkk (2006) adalah tes atomistik. Tes atomistik mengukur butir-butir spesifik, misalnya tatabahasa, bunyi, dan kosa kata yang pada dasarnya tidak ada hubungannya dengan penggunaan bahasa nyata. Lihat dalam Ainin, Evaluasi Dalam Pembelajaran Bahasa Arab (Malang: Misykat, 2006), 70-71.

15 Burhan Nurgiantoro, Penilaian Pembelajaran Bahasa Berbasis Kompetensi, .285.

16 Ibid, . 289. 
Ainin, bahwa yang termasuk tes integratif baik yang menyangkut aspek kebahasaan maupun keterampilan berbahasa adalah a) menyusun kalimat, b) menafsirkan wacana, c) memahami bacaan yang dibaca atau didengar, d) menyusun sebuah alinea berdasarkan kalimat-kalimat yang disediakan. ${ }^{17}$ 4. Pendekatan Pragmatik

Pendekatan pragmatik senafas dengan pendekatan komunikatif dalam konteks pembelajaran bahasa yang menekankan pembentukan kompetensi berbahasa, kemampuan berbahasa dalam fungsi komunikatif yang wajar. Tes pragmatik dapat diartikan sebagai suatu prosedur atau tugas yang menuntut peserta didik untuk menghasilkan urutan-urutan unsur bahasa (konteks linguistik) sesuai dengan pemakaian bahasa itu secara nyata, dan sekaligus menuntut peserta didik untuk menghubungkan unsur-unsur bahasa tersebut dengan konteks ekstralinguistik. ${ }^{18}$ Dalam tes pragmatik tidak lagi ditemui adanya tes struktur atau kosakata atau unsur-unsur kebahasaan dan bahkan langsung dikaitkan dengan unsur ekstralinguistik sekaligus. ${ }^{19}$

5. Pendekatan Komunikatif

Pendekatan ini menekankan pentingnya fungsi bahasa sebagai fungsi komunikasi. Pembelajaran bahasa di sekolah harus memberikan kesempatan kepada peserta didik untuk memperoleh berbagai kompetensi berbahasa yang dapat dimanfaatkan untuk kegiatan berkomunikasi dalam kehidupan

${ }^{17}$ Ainin dkk, Evaluasi Dalam Pembelajaran Bahasa Arab, .74.

${ }^{18}$ Yaitu aspek-aspek pemahaman bahasa di luar apa yang secara eksplisit diungkapkan melalui bahasa, dan yang meliputi segala sesuatu dalam bentuk kejadian, pikiran, antar hubungan, perasaan, persepsi, ingatan, dan lain-lain. Semua itu terekam dalam suasana abstraksi pengalaman hidup yang dapat dimanfaatkan dalam penggunaan bahasa. Lihat dalam Soenardji Djiwandono, Tes Bahasa: Pegangan Bagi Pengajar Bahasa, 25.

19 Burhan Nurgiantoro, Penilaian Pembelajaran Bahasa Berbasis Kompetensi, . 294. 
nyata. Kompetensi berbahasa ${ }^{20}$ itu meliputi kemampuan pemahaman (menyimak dan membaca) dan kemampuan penggunaan (berbicara dan menulis). Dengan demikian, pembelajaran bahasa, dengan konsekuensi penilaiannya harus melibatkan berbagai aspek kebahasaan sekaligus. Inilah kemudian yang dikenal sebagai pembelajaran yang bersifat whole language. Dalam whole language terkandung pengertian keterpaduan antara berbagai fungsi bahasa dengan tata bahasa. Fungsi komunikatif bahasa adalah berupa pemahaman (aktif reseptif) dan penggunaan (aktif produktif) bahasa, sedang tata bahasa adalah semua aspek yang terkait dengan sistem bahasa. ${ }^{21}$

\section{Lingkup Tes Bahasa}

Dalam konteks ini, tes bahasa merupakan alat yang dipakai untuk mencoba mengukur seberapa banyak peserta didik telah menguasai bahasa yang dipelajari. Istilah penguasaan terhadap suatu bahasa yang dipelajari dibedakan menjadi penguasaan terhadap aspek-aspek bahasa, elemen-elemen linguistik, kompetensi linguistik, dan penggunaan bahasa itu untuk kegiatan komunikasi, kompetensi komunikatif, dan

${ }^{20}$ Dalam perspektif Soenarji Djiwandono, kompetensi komunikatif terdiri dari penguasaan terhadap tiga komponen bahasa, yaitu: 1) kemampuan bahasa (language competence), yang meliputi berbagai unsur bahasa yang digunakan dalam berkomunikasi lewat bahasa, termasuk struktur, kosakata, prosodi, makna. 2) kemampuan strategis (strategic competence), yaitu kemampuan untuk menerapkan dan memanfaatkan komponen-komponen kemampuan bahasa dalam berkomunikasi lewat bahasa senyatanya. 3) mekanisme psiko-fisiologis (psychophysiological mechanism), yaitu proses psikis dan neurologis yang digunakan dalam berkomunikasi lewat bahasa. Sederhanany, kemampuan komunikatif didefinisikan sebagai kemampuan untuk menggunakan bahasa sesuai dengan situasi nyata, baik secara reseptif maupun secara produktif. Lihat dalam Soenardji Djiwandono, Tes Bahasa: Pegangan Bagi Pengajar Bahasa, . 28.

21 Burhan Nurgiantoro, Penilaian Pembelajaran Bahasa Berbasis Kompetensi, . 302. 
kompetensi berbahasa. ${ }^{22}$ Sementara itu, Abdul Munip berpendapat bahwa tujuan pembelajaran adalah terjadinya perubahan pengetahuan, sikap dan perilaku dalam diri seorang pelajar sebagai akibat dari proses pembelajaran. ${ }^{23}$ Berdasarkan hal tersebut dapat diasumsikan bahwa secara sederhana tes bahasa merupakan upaya yang dilakukan untuk mengukur kemampuan siswa berkaitan dengan pengetahuan kebahasaan (terdiri dari suara, kosakata, dan gramatika), keterampilan kebahasaan (terdiri dari mendengar, berbicara, membaca, dan menulis), dan sikap kebahasaan.

1. Tes Pengetahuan Kebahasaan

Kompetensi bahasa seseorang berkaitan dengan pengetahuan tentang sistem bahasa, tentang struktur, kosakata, atau seluruh aspek kebahasaan itu, dan bagaimana tiap aspek tersebut saling berhubungan. Tes kompetensi kebahasaan secara garis besar dapat dikelompokkan menjadi tes struktur ${ }^{24}$ dan

22 Ibid. 278.

${ }^{23}$ Abdul Munip, Penilaian Pembelajaran Bahasa Arab (Yogyakarta: FITK UIN Sunan Kalijaga, 2017), 31.

${ }^{24}$ Tes struktur (qawaid) dalam bahasa Arab lebih banyak difokuskan pada tes pembentukan kata (sharf) dan tes pembentukan kalimat (nahwu). Tes pembentukan kata dapat berupa pemahaman siswa terhadap proses pembentukan kata (tashrif) dalam bahasa Arab dan dapat pula berupa penggunaannya, yaitu bagaimana siswa dapat mentashrif kata dalam bahasa Arab dan dapat menggunakannya dalam kalimat. Adapun tes pembentukan kalimat (nahwu) mencakup aspek pemahaman dan penggunaan (tathbiq). Lihat dalam Ainin dkk, Evaluasi Dalam Pembelajaran Bahasa Arab (Malang: Misykat, 2006), 130-131. 
kosakata ${ }^{25}$ dengan tanpa mengabaikan sistem fonologi ${ }^{26}$ (ashwat). ${ }^{27}$ Dalam pembelajaran bahasa, khususnya bahasa kedua dan bahasa asing, kompetensi kebahasaan perlu diajarkan dan diteskan secara khusus karena kompetensi itu dapat dipandang sebagai prasyarat untuk menguasai kompetensi komunikatif, jadi bersifat prakomunikatif, atau tindakan berbahasa baik yang bersifat reseptif maupun produktif. Ditinjau dari segi fungsi komunikatif, tes kompetensi kebahasaan tidak secara langsung mengukur kemampuan berbahasa peserta didik. Pengukuran kemampuan terhadap aspek-aspek tertentu bahasa kurang mencerminkan pemakaian bahasa secara nyata. Karena hanya bertujuan mengukur pengetahuan aspekaspek kebahasaan, tes kompetensi kebahasaan bersifat diskret. $^{28}$

\section{Tes Keterampilan Kebahasaan}

25 Tes kosakata (mufradat) adalah jenis tes yang berkaitan dengan penguasaan makna kosakata bahasa Arab, disamping kemampuan menggunakannya pada konteks atau tempat yang tepat dalam suatu wacana bahasa Arab. Sedangkan bentuk-bentuk tes mufradat bahasa Arab yang dapat digunakan di antaranya adalah: menyebutkan pengertian kata yang dimaksud, melengkapi kalimat, dan menyebutkan padanan kata. Lihat dalam Abdul Hamid, Mengukur Kemampuan Bahasa Arab Untuk Studi Islam (Malang: UIN Maliki-Press, 2010), 33-39.

26 Burhan Nurgiantoro, Penilaian Pembelajaran Bahasa Berbasis Kompetensi, . 280.

27 Tujuan tes bunyi bahasa dimaksudkan untuk memperoleh informasi tentang tingkat penguasaan lafal bunyi bahasa, kemampuan melafalkan bunyi bahasa itu menyangkut aspek bunyi bahasa yang panjangnya bervariasi, mulai dari yang paling kecil dalam bentuk masingmasing bunyi bahasa, sampai kata-kata lepas, frasa, kalimat, dan wacana yang lengkap. Lebih lanjut Abdul Hamid menjelaskan, bahwa penilaian tes bunyi bahasa Arab dilakukan atas dasar ketepatan pelafalan, baik dari segi masing-masing bunyi bahasa Arab, maupun sebagai bagian dari rangkaian bunyi bahasa dalam kata-kata, frasa, kalimat, atau wacana yang meliputi jeda bunyi (waqf), tekanan suara (nabr), dan intonasi (tangim). Adapun beberapa contoh tes bunyi bahasa Arab adalah: membaca dengan suara nyaring, membedakan bunyi bahasa Arab yang mirip, dan melafalkan kata-kata. Lihat dalam Abdul Hamid, Mengukur Kemampuan Bahasa Arab Untuk Studi Islam, .30-33.

${ }^{28}$ Ibid, . 325. 
Tes keterampilan berbahasa Arab meliputi tes kemampuan menyimak, ${ }^{29}$ berbicara, ${ }^{30}$ membaca, ${ }^{31}$ dan menulis. ${ }^{32} \mathrm{Ke}-$

${ }^{29}$ Indikator kompetensi yang diukur dalam tes kemampuan menyimak adalah: 1) kemampuan mengidentifikasi huruf, 2) memahami arti kosakata dan frasa, 3) memahami kalimat, 4) memahami wacana, 5) memberi respon terhadap isi wacana yang disimak. Lihat dalam Ainin dkk, Evaluasi Dalam Pembelajaran Bahasa Arab (Malang: Misykat, 2006), 135. Lebih lanjut, Abdul Khaliq (1989) sebagaimana dikutip Abdul Hamid (2010), membagi tes kemampuan mendengar bahasa Arab menjadi dua bagian, yaitu: tes bunyi bahasa (ikhtibar al-Ashwat) dan tes memahami teks yang didengar (Fahm al-Masmu'). Berikut beberapa contoh tes tersebut: mendengar dan membaca, dikte dan mendengarkan, menyimak dan ingatan, mengidentifikasi bunyi, mengungkapkan kembali, dll. Lihat dalam Abdul Hamid, Mengukur Kemampuan Bahasa Arab Untuk Studi Islam, . 42-47.

${ }^{30}$ Tes kemampuan berbicara bahasa Arab bertujuan untuk mengukur kemampuan siswa dalam menggunakan bahasa Arab secara lancar dan benar dalam berkomunikasi secara lisan. Mengukur kemampuan berbicara bahasa Arab adalah mengukur kemampuan siswa dalam mengekspresikan ide, pikiran, dan perasaan siswa dalam bahasa Arab lisan. Berikut beberapa tes yang bisa digunakan untuk tujuan ini: mendeskripsikan gambar, menceritakan pengalaman, wawancara, berbicara bebas, diskusi, dll. Lihat dalam Abdul Hamid, Mengukur Kemampuan Bahasa Arab Untuk Studi Islam, . 52-62.

${ }^{31}$ Yang dimaksud mengukur kemampuan membaca bahasa Arab pada dasarnya adalah mengukur kemampuan memahami teks bacaan bahasa Arab (fahm al-Maqru'), tetapi ada juga yang menambahnya dengan mengukur kebenaran membaca yang meliputi: kebenaran dalam membaca dari segi pengucapannya, dan kebenaran nahwu dan sharafnya. Berikut beberapa tes yang bisa digunakan untuk tujuan ini: membaca dengan suara keras dan memahami teks bacaan. Lihat dalam Abdul Hamid, Mengukur Kemampuan Bahasa Arab Untuk Studi Islam, . 64-67.

32 Dalam menulis bahasa Arab, ada dua aspek kemampuan yang harus dikembangkan, yaitu kemampuan tekhnis dan kemampuan ibdai (produksi). Yang dimaksud kemampuan tekshnis adalah kemampuan untuk menulis bahasa Arab dengan benar, yang meliputi kebenaran imla (tulisan), qawaid (susunan), dan penggunaan alamat tarqim (tanda baca). Sedangkan yang dimaksud dengan ta'bir ibdai adalah kemampuan mengungkapkan ide, gagasan, pikiran, dan perasaan ke dalam sebuah tulisan berbahasa Arab dengan benar, logis dan sistematis. Ada beberapa tes untuk tujuan ini, diantaranya yaitu: takwin aljumlah, tartib kalimat, tahwil, washf, talkhish, kitabah al-faqrah, kitabah al-maqal, dan kitabah 
mampuan pertama dan kedua dikategorikan sebagai keterampilan reseptif, sedangkan yang ketiga dan keempat dikategorikan sebagai kemampuan produktif didasarkan pada pihak yang pertama kali sebagai inisiatornya. Artinya, dalam kemampuan menyimak dan membaca, yang bertindak sebagai inisiator (komunikator) adalah penutur dan penulis, bukan penyimak dan pembaca. Sementara itu, yang bertindak sebagai inisiator dalam berbicara dan menulis adalah pembicara (penutur) dan penulis adalah pembicara dan penulis. ${ }^{33}$

\section{Tes Sikap Kebahasaan ${ }^{34}$}

Keberhasilan belajar seorang peserta didik ditentukan oleh banyak faktor, salah satunya ranah afektif. Ranah afektif berkaitan dengan watak perilaku perasaan, sikap, minat, emosi, motivasi, kecenderungan, berperilkau, derajaat penerimaan atau penolakan terhadap sesuatu, dan lain-lain. Tiap peserta didik adalah pribadi yang unik yang dalam banyak hal tidak sama dengan orang lain, dan keadaan itu harus dihargai. Semua orang akan merasa dihargai jika eksistensi diri dan afeksinya diperhatikan dan dihormati orang lain, termasuk dari

al-qishash. Lihat dalam Abdul Hamid, Mengukur Kemampuan Bahasa Arab Untuk Studi Islam, . 74-75.

${ }^{33}$ Ainin dkk, Evaluasi Dalam Pembelajaran Bahasa Arab, .133.

${ }^{34}$ Inventori ranah sikap kebahaaan dapat dilakukan dengan tes kesastraan. Hal itu berangkat dari tujuan pembelajaran kesastraan yang berupa perolehan pengalaman siswa berkaitan dengan literer-estetis, humanistis, etis dan moral, filosofis, religius-sufistis-profetis, magis-mistis, psikologis, sosial budaya, dan sosial-politis. Lihat dalam Burhan Nurgiyantoro, Penilaian Pembelajaran Bahasa Berbasis Kompetensi, . 492. Berdasarkan hal tersebut dapat diasumsikan bahwa semakin tinggi kompetensi kesastraan siswa, maka semakin tinggi sikap kebahasaan (motivasi, dan minat) yang dimiliki oleh siswa. Lebih lanjut Burhan Nurgiyantoro menjelaskan, secara garis besar tes kesastraan yaitu: 1) tes kompetensi sastra dengan merespon jawaban. Hal ini terdiri dari tes berdasarkan teks puisi, tes berdasarkan teks fiksi, dan tes berdasarkan teks drama. 2) tes kompetensi sastra dengan menyusun jawaban, tes membuat sinopsis dan parafrase puisi, tes menganalisis kesastraan, dan tes proyek. Lihat penjelasan lebih detail dalam Burhan Nurgiyantoro, Penilaian Pembelajaran Bahasa Berbasis Kompetensi, .461-486. 
gurunya. Faktor afeksi yang tinggi dapat diartikan bahwa peserta didik yang bersangkutan bersikap positif, tertarik, termotivasi, atau komponen afeksi yang lain juga baik. ${ }^{35}$

\section{Pendekatan Humanisme}

Secara etimologi humanisme berasal dari kata latin humanus $^{36}$ dan mempunyai akar kata homo yang berarti manusia. Humanus berarti sifat manusiawi atau sesuai dengan kodrat manusia. Adapun secara terminologis, Dalam Kamus Bahasa Indonesia humanisme diartikan sebagai sebuah aliran (pemikiran) yang bertujuan menghidupkan rasa peri kemanusiaan dan mencita-citakan pergaulan hidup yang lebih baik; dan diartikan pula sebagai paham yang menganggap manusia sebagai objek studi terpenting (bukan alam atau Tuhan). ${ }^{37}$ Lebih lanjut Haryanto Efendi menyatakan bahwa makna humanisme merujuk pada kemampuan manusia sebagai individu yang rasional dan dipakai sebagai ukuran segala bentuk pemahaman terhadap realitas, serta berbagai jalan pikiran yang memfokuskan diri dalam masalah-masalah atau isu-isu yang berhubungan dengan manusia. Dengan kata lain, humanisme merupakan pandangan hidup yang menganggap hidup manusia, harga diri manusia, nilai-nilai kemanusiaan, dan hak-hak asasinya sebagai tujuan utama hidup ini. ${ }^{38}$ Dalam kontek agama Islam, ${ }^{39}$ humanisme adalah upaya memanusiakan manusia sesuai dengan peranannya sebagai abdi dan khalifah

${ }^{35}$ Ibid, . 488-489.

36 Senada dengan istilah tersebut adalah humilis, yang berarti kesederhanaan dan kerendahan hati (kesahajaan). Lawan dari pemaknaan istilah itu, pada awalnya adalah makhluk ciptaan lainnya yang bukan manusia (binatang-binatang dan tumbuh-tumbuhan) dan termasuk pula tatanan segala yang ada, makhluk luar angkasa dan dewa-dewa. Lihat dalam Bambang Sugiharto, Humanisme dan Humaniora, .2-3.

${ }^{37}$ Haryanto al-Fandi, Desain Pembelajaran Yang Demokratis dan $\mathrm{Hu}$ manis (Jogjakarta: Arruz Media, 2011), 71.

${ }^{38}$ Ibid, .74.

${ }^{39}$ Ibid, . 85. 
Allah dibumi yang didasarkan pada prinsip-prinsip yang nyata, fitri, dan rasional. ${ }^{40}$ Sedangkan secara historis, humanisme pada masa Yunani Klasik berangkat dari pertimbanganpertimbangan yang kodrati tentang manusia. Sementara pada abad pertengahan, humanisme berangkat dari keyakinan dasar tentang manusia sebagai makhluk kodrati dan adikodrati. Gerakan humanisme yang dipahami secara spesifik dan murni sebagai gerakan kemanusiaan baru berkembang pada zaman renaisans, terutama berkaitan dengan bangkitnya minat kaum tepelajar (umanisti) untuk mempelajari tulisan-tulisan klasik (Yunani-Romawi)..$^{41}$ Jadi secara historis, kaum umanisti adalah orang-orang yang dipandang sebagai pioneer yang mengembangkan gerakan kesadaran intelektual dengan kembali bersandar pada visi humanisme klasik, paideia. Mereka memperoleh inspirasi tentang kemanusiaan ideal dari literatur-literatur klasik melalui studia humanitatis itu. Dengan kata lain, akar purba humanisme adalah paideia. Paideia dimaksudkan untuk membingkai segala maksud dan usaha manusia dalam rangka merengkuh cita-cita manusia ideal sebagai makhluk individual dan sosial. ${ }^{42}$

Humanisme sebagai gerakan kultural dalam arti luas telah menjadi pemicu berbagai upaya yang diarahkan pada afirmasi bahwa manusia adalah subjek dan pusat gravitasi dan berbagai gerakan yang memperjuangkan keluhuran martabat

${ }^{40}$ Prinsip-prinsip tersebut diantaranya adalah saling mencintai, kasih sayang, menjaga kebersamaan, berpegang teguh pada agama Allah, tidak berselisih, tidak bercerai berai, selalu menghindari permusuhan, menjalin hubungan dengan umat lain yang tidak memusuhi umat Islam dengan jalan saling kenal-mengenal, saling berbuat baik, saling mengasihi, bersikap adil, menjamim kebebasan beragama, saling menghormati dan menjunjung kehormatan diri sendiri, memelihara hak orang lain, dan lain sebagainya. Lihat dalam Haryanto al-Fandi, Desain Pembelajaran Yang Demokratis. ., 89.

${ }^{41}$ Bambang Sugiharto, Humanisme dan Humaniora "Relevansinya dengan Pendidikan" (Jogjakarta: Jalasutra, 2008), . 3.

${ }^{42}$ Ibid, . 5. 
pribadi manusia. Pribadi manusia harus selalu menjadi pusat dan tujuan setiap kegiatan, meminjam kata-kata Immanuel Kant, bertindaklah sedemikian rupa sehingga manusia tidak pernah dijadikan sarana untuk mencapai tujuan lain. Keluhuran martabat manusia tidak terletak pada kepemilikan kodratnya yang sudah jadi dan selesai, tetapi dalam kemampuannya untuk menggunakan intelegensinya dan membuat pilihan bebas. ${ }^{43}$ Manusia memiliki kebebasan untuk menentukan hidupnya sendiri. Dengan kata lain, manusia adalah makhluk otonom yang hidupnya tidak dikendalikan oleh faktor di luar dirinya, tetapi diarahkan dan diatur oleh kekuatan internal yang dimilikinya. ${ }^{44}$ Untuk mengoptimalkan kemampuan segala potensi yang meliputinya, agaknya manusia perlu diarahkan. Upaya dalam mengarahkan manusia agar dapat mengoptimalkan potensinya yang beraneka disebut dengan pendidikan. ${ }^{45}$

Pendidikan adalah usaha terpadu untuk memanusiakan manusia, membentuk karakter sehingga peserta didik menjadi pribadi yang berkeutamaan, terpandang karena memiliki $a r-$ ete dan budaya intelektual. ${ }^{46}$ Melalui pendidikan holistik ${ }^{47}$ diharapkan terbentuk manusia yang mampu menggali makna,

\footnotetext{
${ }^{43}$ Ibid, . 341

44 Ibid, . 342.

45 Ibid, . 343.

${ }^{46} \mathrm{Ibid}$
}

${ }^{47}$ Menurut Jejen Musfah pendidikan holistik adalah pendidikan yang memberikan pemahaman terhadap permasalahan global seperti HAM, keadilan sosial, multikultural, agama, dan pemanasan global, sehingga mampu melahirkan peserta didik yang berwawasan dan berkarakter global serta mampu memberikan solusi terhadap permasalahan kemanusiaan dan perdamaian. Dengan demikian pendidikan holistik bertujuan membentuk peserta didik yang setia memahami persoalan lingkungannya dan berusaha ikut terlibat langsung dalam upaya pemecahan masalah-masalah lokal dan global. Hal ini meniscayakan kompetensi dan militansi yang memadai dari setiap peserta didik tentang diri, lingkungan 
menemukan jati diri, menyadari dan mengembangkan potensi yang dimiliki, mengendalikan naluri, membentuk hati nurani, menumbuhkan rasa kekaguman, dan mampu mengekspresikan perasaan dan pemikirannya secara tepat dan benar. ${ }^{48}$

Dalam konteks pembelajaran bahasa Arab, pendekatan humanisme muncul dalam merespon kebutuhan akan pengajarannya. Dimana menurut Fathul Mujib (2010), pembelajaran bahasa Arab dalam pendekatan konvensional hanya menitikberatkan pada perannya memahami rumus dan aturan semata. Pembelajaran belum mampu memberikan efek fungsional pada proses penjelmaan di tingkat tekhnis kehidupan. Dalam kaitan inilah, pendekatan humanisme dalam pembelajaran bahasa Arab muncul. Dalam paradigma ini, pendidikan lebih mementingkan aspek potensi manusia sebagai makhluk sosial, makhluk religius, hamba Allah, khalifah Allah, serta sebagai individu yang mempunyai potensi intelektual dan spiritual yang tinggi. ${ }^{49}$

\section{Pendekatan Humanisme dalam Tes Pengajaran Bahasa Arab}

Evaluasi merupakan bagian integral dari sistematisasi pembelajaran bahasa Arab yang mengandung unsur pengukuran dan penilaian. Mengajar dan mengevaluasi adalah dwi tunggal yang mesti berjalan beriringan..$^{50}$ Dalam perspektif pendidikan yang humanis, evaluasi pembelajaran harus berdasarkan pada bukti yang baik dan memadai, serta dilakukan

sosial, dan tekhnologi informasi dan komunikasi. Lihat Dalam Jejen Musfah, Pendidikan Holistik "Landasan Lintas Perspektif" (Jakarta: Kencana Prenada Media Group, 2012), 4-5.

${ }^{48}$ Bambang Sugiharto, Humanisme dan Humaniora . 344.

${ }^{49}$ Fathul Mujib, Rekonstruksi Pendidikan Bahasa Arab "Dari Pendekatan Konvensional Ke Integratif Humanis” (Yogyakarta: Pedagogia, 2010), 122.

${ }^{50}$ Maksudin dan Qoim Nurani, Pengembangan Kurikulum Pembelajaran Bahasa Arab (Yogyakarta: Pascasarjana FITK UIN Suka, 2017), 179. 
dengan cara yang adil dan objektif. Penilaian atau evaluasi yang adil menurut Mulyasa, dipengaruhi oleh faktor keakraban, menyeluruh, memiliki kriteria yang jelas, dilakukan dalam kondisi yang tepat, dan dengan instrumen yang tepat pula. Dengan demikian, mampu menunjukkan prestasi belajar peserta didik sebagaimana adanya (objektif). Sebab, dalam pendidikan yang humanistik yang menjadi dasar dari evaluasi belajar adalah bukti yang baik dan memadai. Dalam hal ini ada tiga kualitas untuk dapat menentukan baik atau tidaknya bukti-bukti pendukung penilaian, yakni validity, ${ }^{51}$ realibility, ${ }^{52}$ dan quantity. ${ }^{53}$ Oleh karena itu, sejak merencanakan pelajaran, guru harus sudah menentukan hasil akhir yang diharapkan dari para siswa atas materi yang diajarkan dan apa saja piranti yang dapat dipakai untuk penilaian. Termasuk di dalamnya adalah tes pengajaran.

Dalam konteks tes pengajaran, hendaknya setiap domain yang ada dalam peserta didik (meliputi kognisi, afeksi, dan psikomotori) dilakukan pengetesan secara berimbang. Sebab, jika aspek afektif dan psikomotorik tidak dites, dan hanya menekankan pada ranah kognitif seperti yang terjadi selama ini, berarti proses belajar-mengajar hanya mengejar penumpukan materi dan informasi sehingga tidak humanis. ${ }^{54}$

Dalam domain kognisi, instrumen tes yang bisa digunakan untuk mengevaluasi secara umum terbagi menjadi dua, yaitu: 1) tes obyektif, merupakan item tes yang disusun berbasis

51 Mengacu pada kepatutan dan memadainya interpretasi yang dibuat berdasarkan informasi atau data yang tersedia. Lihat Dalam Haryanto al-Fandi. 267.

52 Mengacu pada kekonsistenan hasil assesment yang dilakukan. Konkretnya, siswa yang sama dapat memperoleh skor yang sama pada dua kesempatan tes pada waktu yang berbeda atau mendapat skor yang sama ketika dievaluasi oleh guru yang berbeda. Ibid. 267.

${ }^{53}$ Menggunakan berbagai macam bukti yang dapat dipercaya. Ibid, .267 .

54 Ibid, 269. 
pada objectivies, yakni tujuan pembelajaran khusus, atau indikator-indikator kompetensi. Adapun bentuk dari tes obyektif ini antara lain: jawaban pendek, benar salah, menjodohkan, dan pilihan ganda. ${ }^{55}$ 2) tes uraian, merupakan instrumen evaluasi yang digunakan untuk mengukur ranah kognisi yang tidak bisa dinilai hanya dengan menggunakan tes obyektif, seperti pengukuran kemampuan siswa dalam menghubungkan fakta dengan prinsip, mengorganisasikan data, dan membuat generalisasi. Dalam konteks ini, siswa tidak disiapkan bahan untuk menjawab soal sebagaimana dalam tes obyektif, tetapi mereka harus mampu mengembangkan jawabannya sendiri dari pengetahuan yang mereka miliki. ${ }^{56}$

Adapun dalam domain afeksi, instrumen tes yang bisa dijadikan bahan untuk evaluasi adalah skala likert dan semantic differential. Secara operasional, skala likert dapat dilakukan dengan cara guru menyampaikan berbagai pernyataan yang disusun sesuai dengan indikator kompetensi tersebut, dan siswa diminta untuk menyatakan pandangan dirinya terhadap pernyataan-pernyataan tersebut dengan lima pilihan, sangat setuju (SS), setuju (S), ragu-ragu (R), tidak setuju (TS), dan sangat tidak setuju (STS). ${ }^{57}$ Sedangkan instrumen tes berbentuk semantic differential yaitu penyajian pernyataan yang mengandung sisi positif dan negatif untuk setiap variabel. Skalanya sama dengan skala likert. Perbedaannya terdapat pada daya jangkaunnya, bila likert itu efektif untuk mengukur sesuatu yang belum terjadi, maka semantic differential sebaliknya. ${ }^{58}$ Sementara dalam domain psikomotori, salah satu

55 Dede Rosyada, Paradigma Pendidikan Demokratis (Jakarta: Kencana Prenada Media, 2007), 188-190.

56 Ibid, .198.

${ }^{57}$ Ibid, . 207.

58 Ibid, . 208. 
instrumen tes yang dapat dijadikan bahan evaluasi adalah analisis tugas (task analysis). ${ }^{59}$

\section{Kesimpulan}

Dalam perspektif pendidikan yang humanis, evaluasi pembelajaran harus berdasarkan pada bukti yang baik dan memadai, serta dilakukan dengan cara yang adil dan objektif. Penilaian atau evaluasi yang adil menurut Mulyasa, dipengaruhi oleh faktor keakraban, menyeluruh, memiliki kriteria yang jelas, dilakukan dalam kondisi yang tepat, dan dengan instrumen yang tepat pula. Dengan demikian, mampu menunjukkan prestasi belajar peserta didik sebagaimana adanya ( $o b$ jektif). Sebab, dalam pendidikan yang humanistik yang menjadi dasar dari evaluasi belajar adalah bukti yang baik dan memadai. Bentuk integralnya, evaluasi yang adil dan objektif membutuhkan instrumen tes yang objektif pula. Dalam kaitan tersebut, untuk mengukur domain kognisi dapat dilakukan dengan: 1) tes objektif: : jawaban pendek, benar salah, menjodohkan, dan pilihan ganda. 2) tes uraian. Sedangkan untuk mengukur domain afeksi dapat dilakukan dengan tes model skala likert dan semantic different. Sementara untuk mengukur domain psikomotor dapat dilakukan dengan tes task analysis.

\section{Daftar Pustaka}

Ainin dkk. Evaluasi Dalam Pembelajaran Bahasa Arab. 2006. Malang: Misykat.

al-Fandi, Haryanto. Desain Pembelajaran Yang Demokratis dan Humanis .2011. Yogjakarta: Arruz Media,

Djiwandono, Soenardi. Tes Bahasa: Pegangan Bagi Pengajar Bahasa. 2011. Jakarta: Anggota IKAPI

${ }^{59}$ Haryanto al-Fandi, Desain Pembelajaran Yang Demokratis, .269. 
Faisal, Sanapiah. Metodologi Penelitian Pendidikan. 1982. Surabaya: Usaha Nasional

Hamid, Abdul. Mengukur Kemampuan Bahasa Arab Untuk Studi Islam. 2010. Malang: UIN-Maliki Press

Hamid, Abdul. Mengukur Kemampuan Bahasa Arab Untuk Studi Islam. 2010. Malang: UIN Maliki-Press

Maksudin dan Qoim Nurani. Pengembangan Kurikulum Pembelajaran Bahasa Arab. 2018. Jogjakarta: Pascasarjana FITK UIN Suka

Muhajir. Arah Baru Pengajaran Bahasa Arab "Filsafat Bahasa, Metode dan Pengembangan Kurikulum". 2017. Yogyakarta: FITK UIN Sunan Kalijaga.

Mujib, Fathul. Rekonstruksi Pendidikan Bahasa Arab "Dari Pendekatan Konvensional Ke Integratif Humans. 2010. Jogjakarta: Bintang Pustaka Abadi.

Munip, Abdul. Penilaian Pembelajaran Bahasa Arab. 2017. Yogyakarta: FITK UIN Sunan Kalijaga

Musfah, Jejen. Pendidikan Holistik "Landasan Lintas Perspektif". 2012. Jakarta: Kencana Prenada Media Group, 2012

Nurgiantoro, Burhan. Penilaian Pembelajaran Bahasa Berbasis Kompetensi. 2013. Yogyakarta: Anggota IKAPI

Purwanto, Ngalim. Prinsip-prinsip dan Tekhnik Evaluasi Pengajaran. 1988. Bandung: Remadja Karya.

Rosyada, Dede. Paradigma Pendidikan Demokratis. 2007. Jakarta: Kencana Prenada Media

Sudijono, Anas. Pengantar Evaluasi Pendidikan. 2011. Jakarta: PT Raja Grafindo Persada

Sugiharto, Bambang. Humanisme dan Humaniora "Relevansinya dengan Pendidikan". 2008. Jogjakarta: Jalasutra 
Muhammad Yusuf

Yusuf, Muri. Asesmen dan Evaluasi Pendidikan. 2015. Jakarta:

Prenadamedia Group 